\title{
Anders opleiden: ook anders werken?
}

De afgelopen vijftien jaar heeft de docentprofessionalisering binnen de medische wereld een belangrijke ontwikkeling doorgemaakt. Begin jaren negentig was het op zijn minst gewaagd om te stellen dat een arts wel eens een didactische training kon gebruiken. $\mathrm{Nu}$ is het binnen de meeste UMC's een structurele activiteit geworden. En als je een willekeurig TMOnummer neemt, dan staat er meestal wel een artikel in over de professionalisering van medisch docenten. Hierbij kunnen termen worden gebezigd die destijds 'not done' waren, zoals het opstellen van een persoonlijk ontwikkelingsplan of reflectie en intervisie op het docentschap.

Ook in beleidsplannen van diverse UMC's wordt gesproken over docentprofessionalisering, een kwalificatiestructuur voor docenten met een passende honorering. Dat betekent ook dat er eisen gesteld worden aan de docent en dat deze dus bepaalde competenties op het gebied van onderwijs moet bezitten dan wel verwerven. We zien dan ook een groeiend aantal initiatieven op lokaal niveau om deze ontwikkelingen in gang te zetten. Terecht stellen Zwierstra en Fick dat krachtige ondersteuning op bestuurlijk niveau en een koppeling aan een functiewaarderingssysteem een belangrijke voorwaarde is om docentprofessionalisering van de grond te krijgen. ${ }^{1}$

Deze ontwikkeling beperkt zich niet tot de initiële opleiding. Ook binnen de vervolgopleidingen is er een groeiend besef van het belang van de didactische kwaliteit van de opleider en het nut van scho- ling daarbij. Dit heeft geleid tot het opstellen van een raamplan voor opleiders in de specialistische vervolgopleidingen. ${ }^{2}$ Nieuwe regels terzake zijn vastgelegd in het kaderbesluit van het Centraal College Medische Specialismen (CCMS). Hierbij kunnen medisch specialistische opleidingen leren van de ervaringen binnen o.a. de huisartsopleiding, waar vanaf het begin opleiders intensief getraind worden.

Op zich zijn dit verheugende ontwikkelingen en je zou dus denken dat een droom hiermee werkelijkheid begint te worden. Toch bekruipt mij tegelijkertijd een angstig voorgevoel. Al jaren weten we namelijk dat het effect van scholing op het gedrag van mensen veel kleiner is dan we denken en hopen. En begin deze week luisterde ik toevallig op de radio naar een interview met Ben Tiggelaar, die stelde dat het een mondiaal gegeven is dat allerlei voornemens en beleidsplannen slechts in een klein aantal gevallen tot daadwerkelijk ander gedrag leiden. ${ }^{3}$ Hoe zal het dus aflopen met al die mooie voornemens in beleidsplannen van UMC's en het CCMS? Wat zal het effect zijn van docentcursussen op het opleiden en leren in de medische praktijk?

Dit overdenkend, vermoed ik dat we ons niet alleen moeten richten op het aanleren van ander gedrag middels de docentcursussen, maar dat er minstens en mogelijk wel nog veel meer aandacht moet komen voor de omgeving waarin het geleerde moet worden toegepast. Om in onderwijskundige termen te blijven: we moeten ons richten op de transfer van het geleerde. 
Dat kan bijvoorbeeld door te zorgen voor follow-up, coaching en intervisie op de werkplek. ${ }^{4}$ Tiggelaar geeft aan dat ons gedrag niet alleen bepaald wordt door onze bewuste voornemens en intenties, maar ook door allerlei prikkels uit de directe omgeving. Die prikkels roepen doorgaans allerlei automatische gewoontegedragingen op. Dit zal voor een medisch specialist mogelijk niet anders zijn. Al jaren horen we dat er zo weinig tijd is voor opleiden, dat "zij wel willen, maar de anderen niet", of dat het in de praktijk toepassen van het geleerde gewoonweg veel moeilijker is dan men oorspronkelijk dacht. We zullen dus ook serieus naar de werkomgeving van de opleider en de opleidersgroep moeten kijken en moeten nagaan welke factoren het toepassen van geleerde dingen stimuleren of juist afremmen. Willen al onze ambitieuze plannen een kans van slagen hebben, dan zal er ook zorgvuldig naar de werkplek gekeken moeten worden waarin het geleerde moet worden toegepast. Welke kansen liggen daar? Welke belemmeringen zijn er en wat moet er gebeuren om ervoor te zorgen dat nieuw gedrag wel een kans krijgt? En dat betekent een herbezinning op de wijze waarop het werk, en daarmee samenhangend het leren, is georganiseerd.

Lia Fluit

\section{Literatuur}

1. Zwierstra RP, Fick ThE. Trainingen voor klinische docenten. Tijdschrift voor Medisch Onderwijs 2004;23(1):51-6.

2. Bolhuis S, Fluit CRMG, Venekamp R, Boendermaker PM. Naar scholing voor opleiders in de specialistische vervolgopleidingen. Tijdschrift voor Medisch Onderwijs 2005;24(2):72-7.

3. Tiggelaar B. Doen! Nieuwe praktische inzichten voor verandering en groei. Utrecht: Het Spectrum; 2003-2005.

4. Govaerts MJB, Bisscheroux TJHI, Merkx ACM, Docentenprofessionalisering door integratie van theoretisch leren, ervaringsleren, intervisie en reflectie. Tijdschrift voor Medisch Onderwijs 2004;23(2):91-9. 